Hyphaema (haemorrhage from the iris) was the commonest finding. It sometimes reduced the vision to a bare perception of light and occasionally caused a secondary glaucoma. In a few cases there was also haemorrhage into the vitreous or retina. Occasionally the cornea was abraded, in one instance even ruptured; in another case the iris root was avulsed, and in one the retinal periphery was torn, leading to a detachment. In five cases spectacles were being worn and were broken by the injury. Happily the outcome was always satisfactory, all of the 35 patients ultimately seeing $6 / 9$ or better.

In his summing-up the author recommends that one-eyed people should not play squash, which may be rather a fierce restriction since all his patients regained good vision, and he further suggests that squash players might protect themselves by wearing unsmashable spectacles. However, most of us would consider this remote risk of eye injury worth taking and will continue to enjoy the game with our naked eyes (or eye), only trusting that some unit as efficient as the Melbourne Eye Hospital is within reach if the worst happens. It could be added that, since all the patients in the London series were wearing glasses, ${ }^{5}$ bespectacled squash players should use toughened or plastic lenses or wear contact lenses.

1 Elkington, A., and Kanski, I. J., British Medical fournal, 1973, 1, 156.

2 Archer, D., and Galloway, N., Lancet, 1967, 2, 487

3 Millar, G. T., American fournal of Ophthalmology, 1967, 64, 741

- North, I. M., Medical fournal of Australia, 1973, 1, 165.

5 Ingram, D. V., and Lewkonia, I., British fournal of Ophthalmology, 1973, in press.

\section{Livingstone's Example}

At his death 100 years ago David Livingstone was a saintly and commanding figure to most of his countrymen. Westminster Abbey was the natural and undisputed repository of his mortal remains, while his exploits and reputation were an encouragement to young people seeking an ideal and an example to their elders bearing religion, commerce, or medicine to the wilder parts of the earth.

The records of people who knew him on his travels or at base disclose a much more complex character than the simple and heroic missionary often depicted by his admirers. There was an element of humbug in his make-up that has in an odd way infected many of the later chroniclers of his work. How could it be possible, they seem to have asked themselves, that so humane a man, so industrious a doctor, so gifted an explorer, so unfaltering a witness to the word of God could have treated his own family and colleagues so unfairly and on occasions spoken of trade as though it were part and parcel of the Christian religion. Some of what we now see as the darker side of the story has fallen into that shadow because the perspective of history has changed. Yet a recent and sympathetic biographer ${ }^{1}$ can only conclude that he failed as a missionary, a geographer, and a liberator; that "it was through his fault that his wife had died untimely; through his neglect that his children were orphaned," and "there was nothing worth-while to show for it all"-except may be added, the inspiration to bring social and technical advancement to remote peoples who had not been touched by the standards of western Europe or, if they had, largely to their detriment.

Judged by the criteria of his time Livingtone did not make patronizing demands on the primitive societies through which he moved in the central parts of southern Africa. He was an accomplished linguist who took the trouble to learn local languages so that he could communicate with the people among whom he travelled, preached, and practised medicine. Despite the rigours of an enthusiasm generated by a deeply felt sense of mission in his youth, Livingstone had the warmest affection for the Africans to whom he ministered. Indeed the contrast has often been remarked of his ability to get on well with the Africans and his acerbity in dealing with European colleagues. Of these, his colleagues and staff, it has been aptly said that "People could only be on friendly terms with him as long as they fell in with his plans."2

It was probably mainly as a medical man that Livingstone won the renown he did among the Africans. Professor $M$. Gelfand has documented this side of his life fully and brought out the many qualities that made the ineffectual geographer an effective doctor under appallingly difficult conditions. A strict disciplinarian in matters of health and hygiene, an accurate observer of unfamiliar diseases, and a devoted worker despite his own ill-health-Livingstone must always be an example of good doctoring to those medical men and women who continue to go out to developing countries in order to practise or teach there.

Elsewhere in the B.M.f. this week Professor G. Shepperson provides a memoir to recall the outlines of Livingstone's life and death. As he rightly says, Livingstone's genius lay in his "personification of the challenge of Africa." That challenge still stands today and attracts medical men to meet it. Nor does it come only from Africa: many parts of the technically undeveloped world are virtually precluded from making a real advance by the burden of disease that weighs on their peoples. The lifting of this burden is a task that Livingstone understood and took on with fortitude.

\footnotetext{
1 Sraver. G., David Livingstone: His Life and Letters. London, Lutter-

worth Press, 1957. Blackwell, 1957.
}

\section{New Horizons in Medical Ethics}

Confronted by codes such as the Declaration of Helsinki and the Medical Research Council document, and the existence of hospital ethical committees, the layman and the doctor outside the field of medical research might be forgiven for supposing that few ethical problems remain there. Not so: the debates on the research programme at Willowbrook hospital and on how valid so-called "informed" consent can ever be have shown that many questions remain unanswered, while new ones are constantly being posed by fresh developments in medicine. A series of tape-recorded discussions which starts at page 220 of this week's B.M.f. is designed to ventilate some of the more important issues in medical ethics today-though not necessarily to provide any clear-cut answers. This week's discussion centres on research investigation in adults, and future ones will cover investigations in children and on the fetus, the problem of malformed children, and changing the patient's personality -as well as more everyday problems such as the relation of doctors to the communications media and some problems of confidentiality. 